\title{
My Teaching and Learning Philosophy
}

\author{
Laila Cassum \\ School of Nursing and Midwifery, Aga Khan University, Karachi, Pakistan \\ Email: laila.akber.mn12@student.aku.edu
}

Received 7 January 2015; accepted 24 January 2015; published 28 January 2015

Copyright (C) 2015 by author and OALib.

This work is licensed under the Creative Commons Attribution International License (CC BY). http://creativecommons.org/licenses/by/4.0/

\section{(c) (i) Open Access}

\begin{abstract}
The teaching learning journey is a dynamic, continuous and challenging process. It is beyond the boundaries to what we learn in schools in our initial years of life. We learn from our environment, positive and negative past experiences, and from the people with whom we interact. It is the teacher who brings an enormous impact on shaping the personality of the learners. Every classroom presents a unique community of learners that vary not only in abilities, but also in learning styles. It is the teacher who provides students with the necessary tools to develop their knowledge and skills and facilitates them to think critically. In addition, when the positive learning atmosphere is coupled with innovative teaching and learning strategies, creates environment conducive for critical and lifelong learning. This paper will highlight on my teaching philosophy under diverse spheres of student, teachers, teaching and learning cycle and the learning environment, and how combined phenomena can foster lifelong learning among learners.
\end{abstract}

\section{Keywords}

Teaching Learning Process, Learning Environment, Teaching Philosophy

Subject Areas: Education

\section{Introduction}

I would like to begin my philosophy paper with the words of William Arthur as cited in [1], "The mediocre teacher tells. The good teacher explains. The superior teacher demonstrates. The great teacher inspires” (p. 334). Philosophy is the love of wisdom, and one of the foundations of education. It incorporates values, beliefs, and ideals that we want to accomplish in our lives. My educational journey is full of memories of great teachers who have left significant impression in my mind and facilitated me in sailing successfully in learning journey till today. It is because of inspiration through their guidance, the learnt values has now transformed as philosophies of my life.

My teaching philosophy has gradually emerged by learning values and morals from home, my mother, my teachers, past experiences, peer discussions at workplace, and reading religious literature. In this paper, I would 
be presenting my teaching philosophy in the context of students, teachers, teaching-learning cycle, and the learning environment.

Learning is not a fixed concept. It is beyond the boundaries to what we learn in schools in our initial years of life. We learn from our environment, positive and negative past experience, people with whom we interact. It is the teacher who brings an enormous impact in shaping the personality of the learners. A learning environment comprises of diverse learners who not only vary in their competencies and potentials but also possess different learning styles. It is the teacher who provides the students with their facilitation and guidance, through which they can acquire new knowledge and skills and improvise the ones which are formerly learnt.

\section{Students}

Thinking from student's perspective, I believe that actual learning is most meaningful when done in a non threatening environment. Casciani [2] mentions that success depends upon three guiding principles: knowledge, critical thinking and curiosity. Students are inquisitive to learn, and when they are motivated to improve, successes are rewarded. Effective learning is the outcome of the successful interaction between a teacher and the student. An academic environment comprises of students from diverse background, and I believe that every learner is unique and has a different learning style. Therefore, considering learning as the core outcome for the students, the facilitator should adapt teaching strategies based on the pace and depth of student understanding capacity.

I have learned the value of asking questions since my childhood, and I believe that welcoming environment where the students are encouraged to ask questions and present their thoughts while respecting the opinions of others, promotes problem solving and critical thinking skills with in students. My teaching philosophy is that I want my students to fearlessly ask questions and that there are no "bad or silly questions". This strategy of the facilitator fosters interest and promotes in-depth understanding of the concept in learners.

Giving and earning respect is a two way process and strengthens relationship between a learner and educator. Being in a student role, I strongly believe that all the students have a right to be respected and the teacher expects the same which helps in inculcating trust in a relationship.

\section{Teacher}

It is an essential that the teachers must be aware of their personal beliefs and philosophies because they are the symbol of inspiration and role model in the minds of the students inside as well as outside the academic environment. Chapnick [3] highlights that skillful, dedicated and effective teacher should have innate qualities like knowledge, skill, devotion, and enthusiasm for teaching. I believe that teachers should be a role model for the students. If I expect from my students to follow certain values and beliefs, the same principle applies for the teacher as well and should do the same.

Teaching and learning is a dynamic process and requires flexibility for a trustworthy relationship between a teacher and a student. Teachers should be student oriented rather task oriented. I believe, that a teacher should serve as a mentor in advising the students for academic assessments and also provide guidance for transforming into successful human beings.

I have a belief that a teacher should be unbiased and unprejudiced in their expectation from the students while marking their assignments. The principle of checking written papers without name and student number prevents the teacher from being judgmental.

The ultimate goal of a teacher is to facilitate learning. I believe that an honest and dedicated teacher's emphasis should be on "Lighting their candle" rather than just dispensing knowledge. Learning is primarily student's responsibility where as imparting knowledge is the educators task. Learning is a kind of a deal, where I believe that the responsibility lies on both the parties. The student should come up with their pre readings in the class to learn, and the teacher to make the session interactive, such that students are actively involved in the learning process. I believe and agree with Damron [4] that, an effective teacher should reflect upon their teaching pedagogy when the student's become passive learners in and not actively participating in class discussion.

In the recent years teaching learning process have undergone change from contemporary educational environment to virtual class room setup. Students are getting accustomed to virtual learning methodology and I strongly consider that teacher should take the change positively rather than adhering to common teaching strategies. Keeping oneself updated with the new trends in teaching and learning assists in meeting needs of the 
learners.

\section{Teaching and Learning Process}

Teaching and learning is a dynamic, integrated, and continuous process of searching knowledge and experiencing it. These are like two wheels of a vehicle without which a learning journey comes to a halt. Hence, it should keep on moving to make this process an enriching and long lasting experience. This principle is not restricted to academic environment, it can be applied even if a person tries out a new food recipe or learning to swim.

In the recent years, this process has diverted from so called orthodox "one man show" to modern pedagogy system of learning. Teaching and learning are reciprocal to each other, and I believe that, it is a transformative process based on input, process, and reflection. I strongly believe on my teaching philosophy which is to impart knowledge in my students in a way which can transform them into "critical thinkers" rather than "rote learners".

Preparing, organizing and presenting information to the students requires thorough and comprehensive brain storming. I believe with the views of Bastable [5] that, action plans are necessary to achieve the determined goals and objectives. I learned this value during my professional education and would like to adhere to this philosophy as proper planning keeps both the learner and teacher focused, with in time frame and with maximum learning as an outcome. I believe that empowering students for learning and reflective thinking is not only the result of a well-planned lesson but also involves appropriate application of teaching leaning strategies.

Billings and Hallstead [6] emphasize that teaching strategies should be selected so that it enhances critical thinking skills in the students. I believe, and it is important to use different teaching strategies according to varying learning styles of the students. It captures student's attention and interest, which will aid in the retention of critical knowledge. Students learn a lot when they are engaged in argumentative discussions such as debate and controversy dilemmas, and case scenarios as it allows the learner to develop rationalization skills and critique on others decisions as well as integration of didactic content in real life. In addition, learners do appreciate lecture format but they learn more in group work as diverse learners of different capacities are involved to enrich learning from one another. Some students are visual learners and learn best through role plays where as some learn using their psychomotor skills.

Knowledge begins with curiosity and curiosity requires questioning. Learning does not entirely rely on the delivery of the content but the questioning skills of both the learner and the teacher plays a significant role in enhancing critical thinking among students. I would like to quote words of a French philosopher, Voltaire, that "Judge a man by his questions rather than by his answers". Deep learning is facilitated through questioning, rather than giving answers. I strongly believe and agree with Billings and Halstead [6] that higher order thinking questions asked by the teacher and the student enhances problem solving and critical thinking skills, necessary for integration in clinical environment.

Billings and Halstead explains [6] that teaching and learning cycle is incomplete without evaluation, necessary to identify strengths and weaknesses in the learner. This is one of the most important steps in the ladder of learning process. Different assessment techniques such as formative and summative assessments should be done to identify gaps and evaluate student learning regularly during the class as well as overall meeting of learning outcome through assignment of grades.

\section{The Learning Environment}

Wang, Woo and Zhao [7] mention that the learning environment includes physical and psychological environment of the class room. The learning environments of academic institutions of modern era are structured where the students are engaged in self-directed learning. A safe, caring and positive learning environment is necessary to provide the support and motivation to the students needed to learn and succeed. The learning atmosphere should be made conducive through proper lightening and ventilation system, cleanliness, comfort, free of noise and distraction. Also, presence of comfortable seating, chairs for group dialogue are important to mention. Cshaped style of seating arrangement allows proper eye contact and demonstrates sense of openness to the flow and reception of information. In addition to it, the learning environment should be having supporting facilities such as computer lab equipped with latest technology, updated library, supporting facilitators, skills lab. Earthman [8] reports that all these characteristics and the quality of physical environment significantly impact on student's learning and achievement.

An academic environment should be secure, non-threatening and democratic for the students to discuss their 
issues comfortably. Every learner should be given right to express their queries and concerns related to the content openly. Kocoska [9] suggests that democratic learning environment allows the learners to freely express their ideas, which can promote self-confidence and balance the relationship of freedom between student and the learner.

\section{Conclusion}

The teaching learning journey is a dynamic, continuous and challenging process. Learning is a treasure which accompanies its owner everywhere and throughout life. Every student must have experienced teachers in their life, who have significantly influenced their philosophy and served as a mentor in achieving their life goals. Here, I would like to end my philosophy paper with the quote of Nikos Kazantzakis that, "True teachers are those who use themselves as bridges over which they invite their students to cross; then, having facilitated their crossing, joyfully collapse, encouraging them to create their own.”

\section{References}

[1] Fred, H.L. (2010) The True Teacher. Texas Heart Institute Journal, 37, 334-335.

[2] Casciani, S.J. (2009) A Teaching Philosophy Built on Knowledge, Critical Thinking and Curiosity. Magna Publication, Mumbai.

[3] Chapnick, A. (2009) Teaching and Philosophy Assumptions. Magna Publication, Mumbai.

[4] Damron, S.W. (2009) Teaching and Advising Philosophy and Style. Magna Publication, Mumbai.

[5] Bastable, S.B. (1997) Nurse as Educators: Principles of Teaching and learning for Nursing Practice. 2nd Edition, Jones and Bartlett, Sudbury.

[6] Billings, M.D. and Halstead, A.J. (2005) Teaching in Nursing. A Guide for Faculty. Elsevier Saunders, Philadelphia.

[7] Wang, Q., Woo H.L. and Zhao, J. (2009) Investigating Critical Thinking and Knowledge Construction in Interactive Learning Environment. Interactive Learning Environment, 17, 95-104. http://dx.doi.org/10.1080/10494820701706320

[8] Earthman, G.I. (2004) Prioritization of 31 Criteria for School Building Adequacy, American Civil Liberties Union Foundation of Maryland. http://www.aclumd.org/aTop\%20Issues/Education\%20Reform/EarthmanFinal10504.pdf

[9] Kocoska, J. (2009) The Student Position in Democratic Classroom. Procedia-Social and Behavioral Sciences, 1, 2429-2431. http://dx.doi.org/10.1016/j.sbspro.2009.01.427 
Scientific Research Publishing (SCIRP) is one of the largest Open Access journal publishers. It is currently publishing more than 200 open access, online, peer-reviewed journals covering a wide range of academic disciplines. SCIRP serves the worldwide academic communities and contributes to the progress and application of science with its publication.

Other selected journals from SCIRP are listed as below. Submit your manuscript to us via either submit@scirp.org or Online Submission Portal.
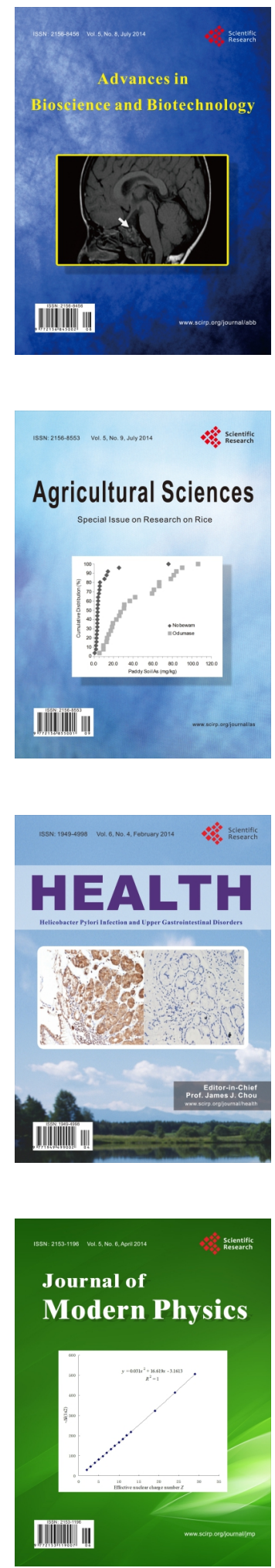
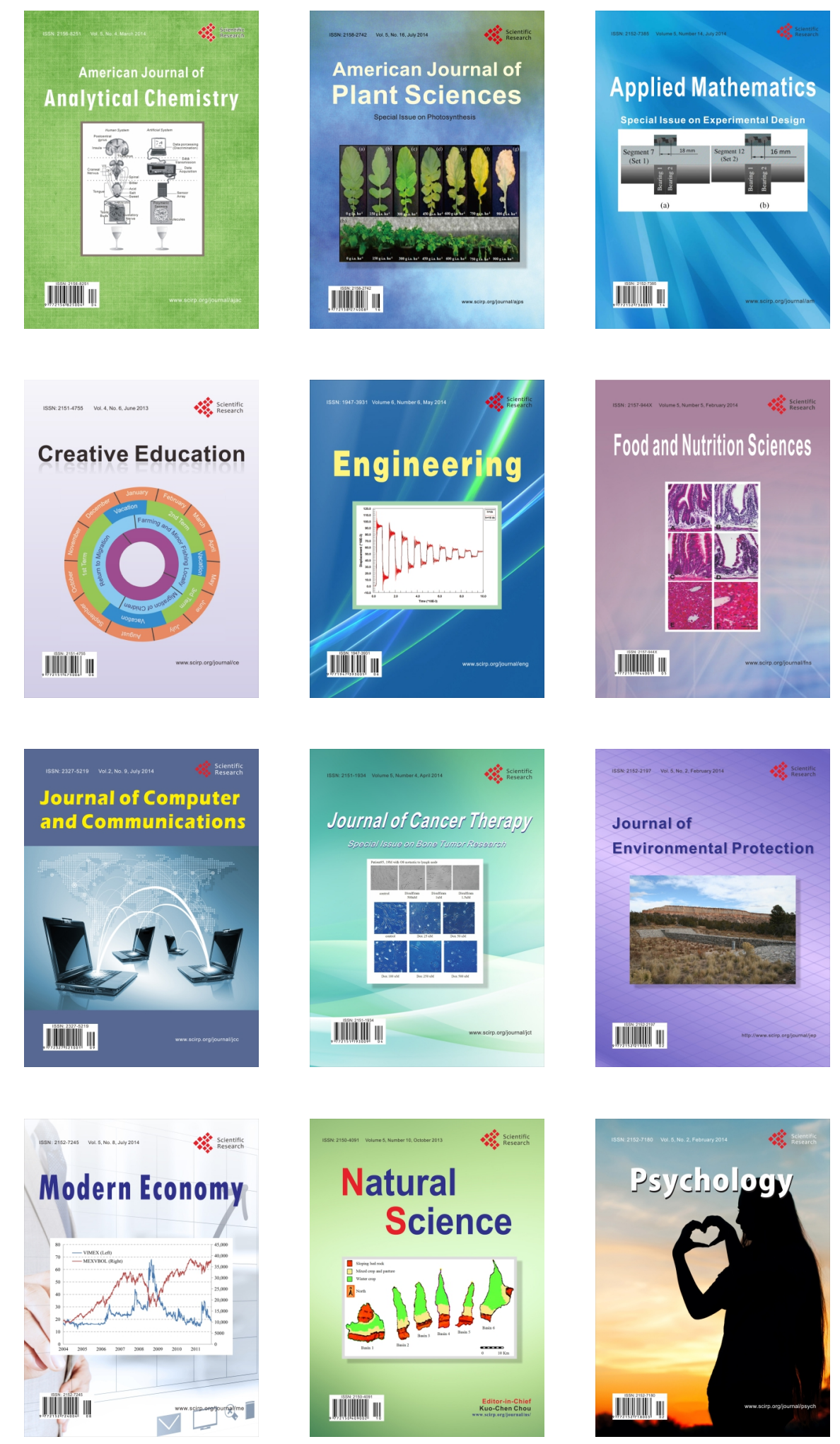